\title{
IDENTIFIKASI PERILAKU ASERTIF PESERTA DIDIK DI MTS MIFTAHUL JANNAH PALANGKARAYA
}

\section{Identification Of Assertive Behavior Of Studentsin Miftahul Jannah Palangkaraya MTs}

\author{
'Darmohing, ${ }^{2}$ Esty Aryani Safithry \\ IUniversitas Muhammadiyah Palangkaraya, Jekan Raya, Palangka Raya, Kalimantan Tengah, Indonesia \\ 2 Universitas Muhammadiyah Palangkaraya, Jekan Raya, Palangka Raya, Kalimantan Tengah, Indonesia
}

\section{ARTIKEL INFO}

Diterima

Juni 2018

\section{Dipublikasi}

Agustus 2018

*E-mail:

esty.aryani.safithry@gmail. com

Orchid: -

\section{ABSTRAK}

Tujuan penelitian ini untuk mengidentifikasi perilaku asertif peserta didik di MTs Miftahul Jannah Palangkaraya Subjek penelitian 8 orang, yang terdiri dari 3 orang peserta didik, 2 orang wali kelas, 2 orang guru mata pelajaran, dan I orang guru BK. Teknik pengumpulan data menggunakan observasi, dan wawancara. Pendekatan penelitian yang digunakan pada penelitian ini adalah kualitatif. Hasil penelitian menunjukan bahwa : Peserta didik di MTs Miftahul Jannah Palangkaraya belum menunjukan perilaku asertif, hal ini ditunjukan dari beberapa aspek perilaku asertif yang belum mampu ditunjukan oleh peserta didik, seperti pada Aspek permintaan, peserta didik belum mampu meminta tanggung jawab dan mempertahankan hak pribadi dengan baik. Pada aspek penolakan peserta didik belum mampu menolak dengan baik, peserta didik tidak mengatakan Ya atau Tidak atas keinginan teman yang negatif. Pada aspek pengekspresian diri, peserta didik sudah dapat mengekspresikan pikiran atau ide, namun belum mampu megungkapkan perasaan dengan benar dan belum mampu member kritik dengan bijaksana. Pada aspek pujian peserta didik belum mampu memberikan dan menerima pujian. Pada aspek berperan dalam pembicaraan, peserta didik dapat mengawali pembicaraan dengan baik, namun belum mampu mengakhiri pembicaraan dengan baik.

Kata Kunci: Perilaku Asertif

\section{ABSTRACT}

The purpose of this study was to identify assertive behavior of students at MTs Miftahul Jannah Palangkaraya. The research subjects were 8 people, consisting of 3 students, 2 homeroom teachers, 2 subject teachers, and I BK teacher. The technique of collecting data uses observation, and interviews. The research approach used in this study is qualitative. The results of the study show that: Students at MTs Miftahul Jannah Palangkaraya have not shown assertive behavior, this is indicated by several aspects of assertive behavior that have not been able to be demonstrated by students, such as in the demand aspect, students have not been able to hold responsibility and maintain personal rights with well. In the aspect of rejection the students have not been able to reject it well, students do not say Yes or No to the negative wishes of friends. In the aspect of selfexpression, students have been able to express thoughts or ideas, but have not been able to express feelings properly and have not been able to criticize wisely. In the aspect of praise, students have not been able to give and receive praise. In the role aspect of the conversation, students can start the conversation well, but have not been able to finish the conversation well.

Keywords: Assertive Behavior 
Jurnal Bimbingan dan Konseling

\section{PENDAHULUAN}

Masa remaja merupakan masa perkembangan transisi antara masa anak-anak dan masa dewasa yang mencakup perubahan biologis, kognitif dan sosial-emosional. Hal yang sangat menonjol pada periode ini adalah kesadaran yang mendalam mengenai diri (self), dimana remaja mulai meyakini akan adanya kemauan, potensi dan cita-cita. Remaja memiliki pemikiran tentang siapakah dirinya dan apa yang membuat diri remaja tersebut berbeda dengan orang lain. Kesadaran remaja yang mendalam mengenai diri ini membuat remaja mampu melakukan penilaian atau evaluasi terhadap diri (Santrock, 2003:26).

Nunally (Andrianidan Marini, 2005:48) mengatakan bahwa penyebab para remaja tersebut terjerumus ke hal-hal negatif, salah satu nya adalah karena kepribadian yang lemah, seperti kurang bisa mengekspresikan diri, menerima umpan balik, me-nyampaikan kritik, menghargai hak dan kewajiban, kurang bisa me-ngendalikan emosi dan agresifitas serta tidak dapat mengatasi masalah dan konflik dengan baik.

Pada hakekatnya peserta didik sebagai manusia merupakan makhluk sosial yang hidup dan berinteraksi dengan lingkungan peserta didikrnya termasuk lingkungan sekolahnya.Oleh karena itu kemampuan komunikasi yang baik sangat ditekankan untuk menciptakan hubungan baik dengan lingkungan pesertadidikrnya. Faktor penting untuk menjadi individu asertif adalah kemampuan untuk bertindak secara konsisten sesuai peserta didik yang peserta didik miliki untuk perilaku peserta didik sendiri.Ketika peserta didik mengatakan kepada diri peserta didik sendiri bahwa orang lain "membuat" peserta didik merasa atau bertindak dengan cara tertentu, peserta didik tidak bertanggung jawab terhadap perilaku peserta didik sendiri.

Berdasarkan latar belakang dari permasalahan di lakukan remaja di atas, maka peneliti ingin mengetahui bagaimana perilaku asertif peserta didik ketika berinteraksi dengan masyarakat sekolah, seperti guru dan teman. Oleh sebab itu peneliti akanm elaksanakan penelitian dengan judul “ Identifikasi perilaku asertif peserta didik MTs Miftahul Jannah Palangkaraya" penelitian ini hanya solusi awal dan bukan solusi total untuk menangani perilaku non asertif peserta didik. Sebagai langkah awal peneliti hanya mengidentifikasi aspek-aspek perilaku asertif peserta didik.

\section{METODOLOGI PENELITIAN}

Pendekatan penelitian merupakan keseluruhan caraatau kegiatan yang mulia dilakukan oleh peneliti dalam melaksanakan penelitian mulai dari masalah sampai dengan menarik kesimpulan. Penelitian menggunakan pendekatan Kualitatifyaitu penelitian yang mengedepankan pengumpulan data atau realities persoalan yang berlandaskan pada pengungkapan apa-apa yang dikumpulkan, dan hal yang dikumpulkan tersebut berupa katakata tertulis maupun tulisan dari orang-orang yang berupa yang diamati. Dengan kata lain, metode deskritif kualitatif adalah suatu prosedur penelitian yang menghasilkan datadata deskritif berupa kata-kata tertulis dan lisan dari orang-orang dan perilaku yang diamati (Moleong. 2002:3).

Jenis penelitian dalam penelitian ini yaitu menggunakan penelitian studi kasus.Menurut Suharsimi Arikunto (2006:24): Penelitian Studi kasus pada khususnya mempelajari secara intensif, terinci dan mendalam terhadap seseorang individu/ kelompok yang dipandang mengalami kasus tertentu.Sedangkan menurut Bimo Walgito (2010:92) studi kasus merupakan suatu metode untuk menyelidiki atau mempelajari suatu kejadian mengenai perseorangan (riwayat hidup). Pada metode studi kasus ini di perlukan banyak informasi guna mendapatkan bahan-bahan yang agak luas. Metode ini merupaka integrasi fdari data yang di peroleh dengan metode lain 


\section{HASIL DAN PEMBAHASAN}

Peserta didik dikatakan dapat menunjukan perilaku asertif dilihat berbagai aspek. Senada yang dikemukan oleh Palmer \& Froehner (2002) bahwa asertivitas terdiri dari aspek permintaan, penolakan, pengekspresian diri, pujian, dan berperan dalam pembicaraan.

\section{a. Permintaan}

Berdasarkan hasil wawancara dengan berbagai sumber yang menjadi subjek penelitian, dapat diketahui bahwa pada aspek permintaan peserta didik hanya dapat menunjukan perilaku asertif pada indikator meminta bantuan, menyadari bahwa teman memiliki hak yang sama, baik itu hak untuk memenuhi keinginan, dan mampu meminta penjelasan dari teman atau guru jika ada materi yang belum dipahami dan tugas yang belum dimengerti

b. Penolakan

Berdasarkan hasil wawancara dan observasi di sekolah MTs Miftahul Jannah Palangkaraya, peserta didik cenderung belum mampu menolak keinginan teman yang dianggap dapat merugikan diri sendiri. Peserta didik lebih memilih menghindar dan mengikuti keinginan teman meskipun tidak senang.

\section{c. Penolakan}

Berdasarkan hasil wawancara dan observasi di sekolah MTs Miftahul Jannah Palangkaraya, peserta didik cenderung belum mampu menolak keinginan teman yang dianggap dapat merugikan diri sendiri. Peserta didik lebih memilih menghindar dan mengikuti keinginan teman meskipun tidak senang.

d. Pengekspresian diri

Berdasarkan hasil wawancara dan observasi di MTs Miftahul Jannah Palangkaraya diketahui bahwa, hanya terdapat beberapa indikator yang dapat ditunjukan peserta didik pada aspek pengekspresian diri. Seperti mampu mengungkapkan pikiran atau ide. Namun peserta didik belum mampu menunjukan perasaan secara tepat dan memberi kritik terhadap teman masih cenderung menyakitkan dan kurang bijaksana. Seharusnya peserta didik yang asertif mampu menyampaikan apa yang dirasakan secara tepat dan mampu memberi kritik yang bijaksana tanpa menyakiti perasaan teman

\section{e. Pujian}

Berdasarkan hasil wawancara dan hasil observasi di sekolah MTs Miftahul Jannah Palangkaraya, peserta didik cendertung tidak dapat memberi pujian dan tidak dapat menerima pujian dengan tulus. Peserta didik mengira teman yang memberi pujian hanya mengejek. Seharusnya peserta didik yang aserti dapat menerima dan memberi pujian dengan baik.

\section{f. Berperan dalam pembicaraan}

Berdasarkan hasil wawancara dan observasi di sekolah MTs Miftahul Jannah Palangkaraya, peserta didik sudah dapat mengawali pembicaraan dengan baik, hanya saja belum mampu mengakhiri pembicaraan dengan baik. Seharusnya peserta didik yang asertif dapat memulai dan mengakhiri pembicaraan dengan baik

Berdasarkan hasil yang diperoleh dalam penelitian ini adalah tentang perilaku asertif yang tidak ditunjukkan peserta didik ketika di sekolah, sehingga hubungan interpersonal peserta didik cenderung tergangu. Berikut akan dipaparkan hasil temun penelitian baik bedasarkan hasil wawancara dan hasil observasi dengan ke 8 subjek penelitian

\section{KESIMPULAN}

Berdasarkan hasil temuan penelitian pada Pesertaddiik di MTs Miftahul Jannah Palangka raya belum menunjukan perilaku asertif, hal ini di tunjukan dari beberapa aspek perilaku asertif yang belum mampu ditunjukan oleh peserta didik, seperti pada.

Aspek permintaan, peserta didik belum mampu meminta tanggung jawab dan mempertahan kan hak pribadi dengan baik. Pada asepek penolakan peserta didik belum 
mampu menolak dengan baik, peserta didik tidak mengatakan $\mathrm{Ya}$ atau Tidak atas keinginan teman yang negatif.

Pada aspek pengekspresian diri, peserta didik sudah dapat mengekspresikan pikiran atau ide, namun belum mampu megungkapkan perasaan dengan benar dan belum mampu memberi kritik dengan bijaksana.

Pada aspek pujian peserta didik belum mampu memberikan dan menerima pujian. Pada aspek berperan dalam pembicaraan, peserta didik dapat mengawali pembicaraan dengan baik, namun belum mampu mengakhiri pembicaraan dengan baik.

\section{DAFTAR PUSTAKA}

Andriani, Elvidan Marini, Liza. 2005. Perbedaan Asertivitas Remaja Ditinjau Dari Pola Asuh Orang Tua. Jurnal Psikologi (Vol 4 No. 2 Desember 2007). Hal: 46-5I.

Bimo Walgito. 20l0. Pengantar Psikologi Umum. Yogyakarta: C.V Andi. Offset

Moleong, Lexy. 2002. Metodologi Penelitian Kualitatif. Bandung: PT. remaja Rosdakarya

Santrock, John W. 2003. Adolescence (Perkembangan Remaja). Alih bahasa: Shinto B. Adelar. Jakarta: Erlangga. 